\title{
A FUNÇÃO SOCIAL DA PROPRIEDADE URBANA
}

\section{THE SOCIAL FUNCTION OF URBAN PROPERTY}

\author{
${ }^{1}$ Juliana Aparecida Gomes Oliveira \\ ${ }^{2}$ Luiza Machado Farhat Benedito
}

\section{RESUMO}

Este artigo científico tem como objeto de estudo a aplicabilidade do instituto da função social da propriedade urbana no âmbito imobiliário. Para alcançar esta finalidade, faz-se um breve histórico do surgimento da função social da propriedade, diferenciando os termos propriedade e domínio, no intuito de que seja compreendida a função social da propriedade como limitação ao exercício das faculdades inerentes ao proprietário, considerando-a como uma relação juridicamente tutelada, na qual a coletividade ocupa um dos polos desta conexão. Neste diapasão, demonstram-se os desdobramentos da função social refletida na utilização dos imóveis urbanos, com fundamento nos comandos constitucionais, bem como nas leis infraconstitucionais que por força de delegação constitucional possuem o poder de polícia para compelir o exercício da propriedade conforme os moldes estabelecidos. No âmbito do direito urbanístico, esta pesquisa desenvolve um estudo a cerca da regularização fundiária urbana de interesse social. Para isto, foi utilizado o marco teórico que se definiu a partir da Constituição da República do Brasil (CR/88) ao consagrar a função social como um dever de cumprimento do direito fundamental de propriedade, bem como, o uso da metodologia teórica e da revisão bibliográfica, com estudos doutrinários e jurisprudenciais, bem como a análise de leis infraconstitucionais permitindo, assim, verificar a amplitude da função social da propriedade, a sua influência nos processos de urbanização e a utilização desta como ferramenta que visa tornar possível a concretização de um país mais justo e igualitário.

Palavras-chave: Função social da propriedade, Regularização fundiária, Propriedade e domínio

\footnotetext{
${ }^{1}$ Mestranda em Instituições Sociais, Direito e Democracia pela Universidade Federal de Minas Gerais - UFMG, Minas Gerais (Brasil). Escrevente no 4 Ofício de Registro de Imóveis de Belo Horizonte - 4RIBH,Minas Gerais (Brasil). E-mail: julianagoliveira@live.com

${ }^{2}$ Mestranda em Instituições Sociais, Direito e Democracia pela Universidade Federal de Minas Gerais - UFMG, Minas Gerais (Brasil). E-mail: luizafarhatadv@gmail.com
} 


\begin{abstract}
This scientific article is an object of study the applicability of the institute of the social function of urban property in the real estate sphere. To achieve this purpose, it is a brief history of the rise of the social function of property, differentiating the terms "property" and "domain" in order to be understood that the social function of property as exercise limitation inherent to the owner colleges considering it as a juridically protected relationship in which the community is at one pole of this connection. In this vein, the developments reflected social function in the use of urban property to show themselves, on the basis of constitutional provisions as well as the infra laws for constitutional delegation of power have the police power to compel the exercise of property as established molds. Under the urban law, this research develops a study about the urban land regularization of social interest. For this, the theoretical framework defined by the Constitution of the Republic of Brazil/1988 to enshrine the social function as a fulfillment of duty of the fundamental right to property was used; as well as the use of theoretical methodology and literature review, with doctrinal and jurisprudential studies and analysis of infra laws thus allowing verify the extent of the social function of property, its influence on urbanization processes and the use of this as a tool aimed at making possible the realization of a more just and egalitarian country.
\end{abstract}

Keywords/Palabras-claves/Mots-clés: Function social of property, Regularization, Property and domain 


\section{INTRODUÇÃO}

A informalidade urbana tem sido um dos fatores preocupantes no Brasil. A ocupação irregular dos diversos espaços públicos e privados, ocorre, na maioria das vezes, por população de baixa renda que, por fatores históricos e culturais, não tiveram a oportunidade de produzir formalmente os locais onde vivem.

A prima facie, pode-se pressupor que tal aspecto informal traz consigo certos "benefícios", haja vista que a informalidade resulta na não incidência de alguns deveres inerentes ao proprietário, como por exemplo, o pagamento do imposto Predial e Territorial Urbano (IPTU). Não obstante, feitas essas ponderações, se torna imprescindível destacar que há, por outro lado, a perda de proteção jurídica inerente à dignidade pessoa humana, e esta, por sua vez, não consiste em algo que seja economicamente apreciável. A produção informal de habitação traz consigo consequências tais como o impedimento do exercício da cidadania, a falta de segurança, de saúde, de educação, entre a inoperância de outros direitos assegurados constitucionalmente.

Fato é que, ao consagrar a função social como um dever de cumprimento do direito fundamental de propriedade, a Constituição da República do Brasil (CR/88) introduziu a coletividade nesta relação jurídica. Isso possibilitou a legitimação de direitos e fundamentos para a regularização dessas moradias.

A função social da propriedade como concepção ativa e comissiva, faz com que o exercício das faculdades inerentes ao proprietário, sejam exercidas de forma a atender ao bem comum. Se por um lado a obrigação de fazer consiste no comprometimento do cumprimento da função social, a obrigação de não fazer advém do poder de polícia conferido à administração pública.

Nesta perspectiva, a regularização fundiária tem como objetivo intervir na gestão de territórios urbanos com fundamento no princípio da função social da propriedade, através de medidas jurídicas, ambientais, urbanísticas e sociais visando adequar os assentamentos irregulares, promovendo a cidadania, o direito à moradia e consequentemente, objetivando a efetivação do princípio norteador das normatizações, qual seja: a dignidade da pessoa humana.

Assim, será realizado um estudo científico quanto à aplicabilidade do instituto da função social da propriedade urbana no âmbito imobiliário, inicialmente diferenciando os termos "propriedade" e "domínio", para compreensão da função social da propriedade como 
limitação ao exercício das faculdades inerentes ao proprietário, considerando-a como uma relação juridicamente tutelada, na qual a coletividade ocupa um dos polos desta conexão.

Neste diapasão, será demonstrado os desdobramentos da função social refletida na utilização dos imóveis urbanos, com fundamento nos comandos Constitucionais, bem como nas leis infraconstitucionais. No âmbito do direito urbanístico há o enfoque a cerca da regularização fundiária urbana de interesse social.

Para a construção deste artigo científico foi utilizado o marco teórico que se definiu a partir da Constituição da República do Brasil (CR/88) ao consagrar a função social como um dever de cumprimento do direito fundamental de propriedade e, a metodologia teórica e da revisão bibliográfica, com estudos doutrinários e jurisprudenciais, bem como a análise de leis infraconstitucionais permitindo, assim, verificar a amplitude da função social da propriedade, a sua influência nos processos de urbanização e a utilização desta como ferramenta que visa tornar possível a concretização de um país mais justo e igualitário.

\section{FUNÇÃO SOCIAL DA PROPRIEDADE IMOBILIÁRIA - BREVE HISTÓRICO}

O instituto jurídico da propriedade teve origem no Direito Romano e definia-se como ius utendi, fruendi et abutendi, ou seja, direito de usar, fruir e dispor. No entanto, essas possibilidades eram intrinsicamente ligadas à cultura mística.

A propriedade se vinculava à religiosidade na qual era possível somente aos cidadãos romanos a aquisição de imóveis no solo romano, e as razões se justificavam pelo culto religioso aos mortos. As famílias cultuavam seus próprios antepassados como deuses, chamados de lares ou manes ${ }^{l}$. Segundo a crença, os ancestrais não morriam, continuavam a ocupar o solo em que viviam, mesmo após a morte carnal, assim, resta justificada a importância do solo para as famílias que o considerava sagrado.

A evolução histórica fez com que a propriedade perdesse esse caráter místico, principalmente após a invasão dos bárbaros que resultou na queda do Império Romano do Ocidente, momento em que alguns proprietários tiveram que entregar suas terras aos grandes senhores em troca de segurança, tornando-se vassalos eternamente dependentes dos grandes feudos.

\footnotetext{
1 Lares ou Manes são divindades domésticas romanas, cultuados no culto doméstico primitivo como personificações de seus antepassados.
} 
O desenvolvimento das cidades e do comércio colocou fim a esse cenário, dando lugar à burguesia que buscava a criação de uma monarquia absoluta e do Estado Nacional, o que culminou na democratização da propriedade. No entanto, a monarquia se tornou grande empecilho ao desenvolvimento do capitalismo pelo seu sistema obsoleto, o que resultou em uma gama de pensadores desconformados com a realidade e com ideais (revolucionários) para alterar a ótica absolutista. Por força do Iluminismo e do Liberalismo ocorreram três grandes revoluções: A Revolução Gloriosa, na Inglaterra, a Revolução Americana pela Independência e a Revolução Francesa. (FIÚZA, 2012, p. 835-836).

A evolução da propriedade absoluta para a propriedade-função é consequência de transformações sociais, econômicas e políticas, com influência de matrizes filosóficas do direito. Em síntese, essas mudanças sociais culminaram na alteração da concepção de "propriedade" com um viés de equilíbrio social.

Todo esse emaranhado de acontecimentos pode ser vislumbrado nos dizeres de (GRAU, 1977, p. 63) que sintetiza o arcabouço da evolução da propriedade afirmando ser este "a revanche da Grécia sobre Roma, da filosofia sobre o direito: concepção romana que justifica a propriedade por sua origem (família, dote, estabilidade de patrimônios), sucumbe diante da concepção aristotélica, que a justifica por seu fim, seus serviços, sua função".

A concepção de propriedade como mera apropriação dos bens, sem que esse bem tivesse uma interação com a coletividade, ainda se encontrava presente no estágio inicial da evolução do capitalismo. Essa concepção se dava, principalmente, pela cultura da época, que consistia em incentivar a intensificação da produção e a obtenção de lucro com a finalidade de aquisição de propriedade.

A preocupação social em relação aos impactos advindos da autonomia privada exacerbada se deu em fase posterior, com a sedimentação da nova ordem econômica do capital. Inicialmente, acreditou-se que a controle feito pelo ordenamento seria inviável, haja vista que o não controle acarretaria na geração de riquezas, beneficiando, mesmo que de forma indireta, toda a coletividade.

Certo é que, todas essas dúvidas decorrentes do novo sistema conjeturavam uma nova concepção do Direito de Propriedade. A igualdade formal, bem como a liberdade individual almejada pela sociedade não coexistiam harmoniosamente com a realidade de desequilíbrio econômico. Não se pode olvidar que tais valores conflitavam com aquela obsoleta compreensão de liberdade de poucos em prol da opressão de uma massa de pessoas 
privadas de bens que traduziam um mínimo existencial. FARIAS e ROSENVALD (2011) se referem a esse período enunciando que, in verbis:

\begin{abstract}
Atingimos um momento de profunda decepção, diante da constatação da fragilidade do ser humano. Ao contrário do que preconizavam os arautos do racionalismo, a inteligência humana produziu a liberdade, mas não nos permitiu enxergar o outro. Tornamo-nos cegos, e surdos diante do que nos cercam. (FARIAS; ROSENVALD, 2011, p.234).
\end{abstract}

A preocupação em garantir o princípio da solidariedade bem como de tutelar a dignidade da pessoa humana, resultou em uma maior credibilidade aos direitos de personalidade e, por consequência, uma submissão das relações patrimoniais.

A Constituição da República de 1988 (CR/88) traz um rol que estabelece os direitos e garantias fundamentais ${ }^{2}$, na qual o indivíduo não exerce a atividade econômica isoladamente, se torna uma pessoa solidária que se relaciona com a sociedade e encontra na necessidade do outro o limite que impede a liberdade de sua atuação.

Sendo assim, conforme orienta Kildare Gonçalves Carvalho (2010), “a propriedade, sem deixar de ser privada, se socializou, com isso significando que deve oferecer à coletividade uma maior utilidade, dentro da concepção de que o social orienta o individual”.

Isso se torna evidente no artigo 170 da Constituição Federa que dispõe que a ordem econômica tem por fim assegurar uma existência digna conforme os ditames da justiça social, devendo, para tanto, ser observados tais princípios:

\footnotetext{
I - soberania nacional; II - propriedade privada; III - função social da propriedade; IV - livre concorrência; V - defesa do consumidor; VI - defesa do meio ambiente, inclusive mediante tratamento diferenciado conforme o impacto ambiental dos produtos e serviços e de seus processos de elaboração e prestação; VII - redução das desigualdades regionais e sociais; VIII - busca do pleno emprego; tratamento favorecido para as empresas de pequeno porte constituídas sob as leis brasileiras e que tenham sua sede e administração no País. (BRASIL; 1988).
}

É possível verificar a partir desse momento a existência de Direito Civil Constitucional e da dignidade da pessoa humana no qual, através das normas de caráter superior e vinculante, se traduz um Estado Democrático de Direito que impõe vários deveres extrapatrimoniais nas relações privadas limitando a atividade econômica e tutelando direitos essenciais ao ser humano. Conforme orienta Kildare Gonçalves Carvalho (2010):

\footnotetext{
${ }^{2}$ São Direitos e Garantias fundamentais (que norteiam as noções básicas e centrais quanto à vida social, política e jurídica de todos os cidadãos brasileiros), asseguradas pela Constituição da República do Brasil (CR/88), as previsões dos artigos $5^{\circ}$, principalmente, estendendo-se em demais artigos da Magna Carta (CR/88).
} 
O princípio Incide sobre a estrutura e o conteúdo da propriedade, sobre a própria configuração do direito, e constitui elemento que qualifica a situação jurídica considerada, condicionando os modos de aquisição, uso, gozo e disposição dos bens. Não envolve, portanto, apenas limitação do exercício das faculdades do proprietário inerentes ao domínio. A função social da propriedade introduz, na esfera endógena do direito, um interesse que pode até mesmo não coincidir com o do proprietário, com o predomínio do social sobre o individual, fenômeno denominado de sociedade. (CARVALHO; 2010, p.832)

No início, verificou-se que o positivismo tornara-se insuficiente para alcançar o comando constitucional, o que justifica a importância da interpretação conforme a constituição que pressupõe que as leis infraconstitucionais devam ser interpretadas a partir da lei maior.

Neste contexto, todo o sistema legal viabiliza o alcance do que se pretende a Constituição da República, tutelando em conjunto, direitos essenciais aos seres humanos. Milaré (2004) afirma que:

Concebida como direito fundamental, a propriedade não é, contudo, aquele direito que se possa erigir à suprema condição de ilimitado e inatingível. Daí o acerto do legislador em proclamar, de maneira veemente, que o uso da propriedade será condicionado ao bem-estar social. (MILARÉ, 2004, p.120)

Deste modo, o Estado democrático que se constrói hoje consiste na junção do equilíbrio da autonomia privada e das disposições de ordem pública, fazendo com que a liberdade individual esteja em consonância com os interesses coletivos. No entanto, esta liberdade não consiste naquela vislumbrada no Estado Liberal, mas um equilíbrio entre este e o Estado Social.

\section{DOMÍNIO E PROPRIEDADE}

O artigo 1.228 do Código Civil define propriedade como sendo o exercício das faculdades de uso, gozo, disposição e reivindicação da coisa. No entanto, malgrado essa definição seja a mais utilizada para se fazer referência sobre o tema, é possível verificar que se encontra tanto quando obsoleta frente a um Estado Democrático de Direito vinculado à aquela noção de "ter como seu" sem que se tenha essa preocupação de relação da propriedade com a coletividade.

Mister se faz a distinção dos termos propriedade e domínio para que, partindo das considerações que serão feitas, seja compreensível a função social da propriedade. Nelson Rosenvald e Cristiano Farias (2011) diferenciam propriedade e domínio ao expressar que: 
Se a propriedade é observada pela lógica da relação jurídica nela edificada, a seu turno o domínio repousa na relação material de submissão direta e imediata da coisa ao poder de seu titular, mediante o senhorio, pelo exercício das faculdades de uso, gozo e disposição. O proprietário exercita ingerência sobre coisas (domínio) e pede a colaboração de pessoas (propriedade). (FARIAS; ROSENVALD, 2011, p.200).

A definição ora referenciada, decorre da análise no qual se entende que domínio e propriedade consistem em conceitos complementares que coexistem. Os autores supracitados entendem propriedade como um direito complexo que concede ao titular do bem exercer aquelas faculdades existentes no artigo 1.228 do Código Civil. Neste talante, o direito de propriedade é uma relação complexa que nasce entre proprietário, o bem e a coletividade.

Diferente daquela antiga concepção, a propriedade não é a materialização da coisa, ou seja, a propriedade não é aquela característica física do imóvel, mas um reconhecimento legal da dessa relação complexa que consiste na representatividade juridicamente protegida. Essa proteção pode ser vislumbrada, por exemplo, nos cartórios de registros de imóveis e é sintetizada, com mestria, por Nelson Rosenvald e Cristiano Chaves de Faria:

\footnotetext{
O título representativo da propriedade é apenas a parte visível de um bem intangível que resume um conjunto integrado e incontrolável de informações que circulam entre cartórios, registros, instituições financeiras e Estado, promovendo segurança e confiança intersubjetiva. (FARIAS; ROSENVALD, 2011, p. 199).
}

Neste diapasão, ainda que os termos domínio e propriedade sejam utilizados como sinônimos, pode-se afirmar que são conceitos distintos, posto que, enquanto o domínio se refere a um poder se senhorio exercido sobre o bem, a propriedade consiste em uma relação complexa, juridicamente tutelada.

O domínio nem sempre será exercido pelo proprietário do bem, visto que, somente na propriedade alodial (ou plena) é que os poderes inerentes ao proprietário são exercidos unicamente pelo titular da propriedade, verificando-se assim o domínio e a propriedade sendo exercidos pelo mesmo indivíduo.

Mister salientar que a reivindicação inerente ao proprietário, a prima facie, advém da proteção jurídica que recai sobre a propriedade, permitindo àquele que tiver esse direito violado, sancionar à outrem que tiver possuído a coisa injustificadamente, mesmo que tenha o domínio, ou seja, mesmo que este exerça o poder de senhorio sobre o bem.

Pode-se perceber, segundo orientação de Nelson Rosenvald e Cristiano Farias (2011) que em "várias situações o proprietário - detentor da titularidade formal - não será aquele que 
exerce o domínio (v.g, usucapião antes do registro; promessa de compra e venda após quitação)".

Com efeito, a compreensão de propriedade como uma relação jurídica, afasta aquele absolutismo que entende ser esta o poder de uma pessoa sobre um objeto, faz-se, consequentemente, uma interpretação da Lei Civil conforme a Constituição e traduz a intenção do legislador ao inserir, como direito fundamental, a função social.

A propriedade no Estado Democrático de Direito não permite a utilização do bem sem que haja a preocupação em atender ao bem comum, ou seja, a coletividade deve estar inserida nesta relação jurídica. Por fim, é preciso que se tenha um conceito constitucional de propriedade, conforme orienta Bastos (2004):

\footnotetext{
O conceito constitucional de propriedade é mais lato do que aquele de que se serve o direito privado. É que do ponto de vista da lei maior tornou-se necessário estender a mesma proteção, que, no início, só se referia à relação do homem com as coisas à titularidade da exploração de inventos e criações artísticas de obras literárias e até mesmo a direitos em geral que hoje não o são à medida que haja uma devida indenização de sua expressão econômica. (BASTOS, 2011, p. 202).
}

Assim, o Código Civil já se encontra obsoleto ao inserir os termos propriedade e domínio como sinônimos. O diploma supracitado introduz os termos como se estivesse na época em que a propriedade resumia-se no poder de senhorio que uma pessoa exercia sobre um bem, sem que precisasse, no entanto, relacionar-se com a coletividade a fim de atender ao interesse social. Por esta razão, a utilização dos termos propriedade e domínio em um Estado Democrático de Direito, traduz muito mais que isto.

\section{FUNÇÃO SOCIAL DA PROPRIEDADE URBANA}

A constituição Federal não apenas previu o cumprimento da função social entre os direitos e garantias individuais, como também estabeleceu, no artigo 182, que a política de desenvolvimento urbano deve "ordenar o pleno desenvolvimento das funções sociais das cidades e garantir o bem-estar de seus habitantes".

Assim, a ordenação das cidades bem como a organização dos espaços públicos devem propiciar aos cidadãos melhores condições que contribuam para um mínimo existencial, objetivando alcançar a cidadania e a solidariedade. 
Destaca-se que a Constituição da República delega ao Município a fiscalização do cumprimento da função social da propriedade urbana ao instituir, no Artigo 182, § $1^{\circ}$, que o plano diretor é "o instrumento básico da política de desenvolvimento e expansão urbana".

Com a intenção de se fazer cumprir o que se estabelece no artigo supracitado, a Lei $\mathrm{n}^{\circ}$ 10.257/01 estabeleceu diretrizes gerais da política urbana, instituindo, no parágrafo único do Artigo $1^{\circ}$, que "para todos os efeitos, esta lei, denominada Estatuto da Cidade, estabelece normas de ordem pública e interesse social que regulam o uso da propriedade urbana em prol do bem coletivo, da segurança e do bem-estar dos cidadãos, bem como do equilíbrio ambiental".

A Lei $\mathrm{n}^{\mathrm{o}}$ 10.257/01 regulamentou uma obrigação advinda da Constituição da República, impondo ao Município a criação de meios que propicie o uso dos espaços públicos em prol da coletividade, essa premissa deve ser alcançada pelas leis orgânicas (nas cidades de porte reduzido), bem como com a construção do plano diretor (requisito obrigatório para cidades com mais de vinte mil habitantes e municípios que integrem áreas de especial interesse turístico).

Destarte, por meio desses instrumentos os Municípios atendem ao comando constitucional do artigo 182, $\S 2^{\circ}$, que estabelece que "a propriedade urbana cumpre sua função social, quando atende às exigências fundamentais de ordenação de cidade expressas no plano diretor" através de uma política de desenvolvimento urbano que garanta o bem-estar de seus habitantes.

Mais que criar formas de se alcançar a função social, tem-se que, para os Municípios que deixarem de exigir um comportamento positivo dos proprietários, a Constituição da República prevê a inconstitucionalidade por omissão no artigo $103, \S 2^{\circ}$, como forma de sancionar por descumprimento do preceito normativo.

Ademais, é por meio do Plano Diretor que se torna possível aplicar as medidas de parcelamento ou edificação compulsório, o Imposto Predial e Territorial Urbano (IPTU) progressivo e a desapropriação. São por meio dessas medidas que o Município busca alcançar a função social da propriedade, bem como efetivar o seu cumprimento.

Inicialmente, o artigo 50 da Lei no 10.257/01, determinou que os planos diretores dos Municípios deveriam ser aprovados até dia 10 de outubro de 2006, no entanto, frente à inércia de alguns administradores, houve prorrogação do prazo para 30 de junho de 2008. Isso demonstra o grau de prioridade que alguns administradores conferem ao cumprimento da função social da propriedade urbana. Conforme orienta Nelson Rosenvald e Cristiano Farias: 


\begin{abstract}
Mesmo para os municípios menores, onde não há a obrigatoriedade da edição do plano diretor, os mesmos problemas de informalidade urbana e degradação ambiental ocorrem. Aliás, inútil será a edição da tão festejada norma federal que delimita as linhas gerais da política urbana se os municípios não cuidarem de concretizá-la, adaptando a sua legislação às diretrizes do Estatuto da Cidade, de modo a combater a grave crise urbana e habitacional hoje vivenciada. (ROSENVALD; FARIAS, 2011, p. 252).
\end{abstract}

A função social da cidade ocorre quando suas riquezas são distribuídas de forma justa a fim de combater desigualdades sociais e econômicas, bem como a segregação social, garantindo, assim, um desenvolvimento urbano sustentável tutelando os direitos humanos e promovendo a dignidade da pessoa humana.

Por isso, se impõe ao proprietário uma conduta na qual sua propriedade não se torne empecilho ao desenvolvimento urbano. Neste sentido "a propriedade urbana que não atende a função social é aquela que frustra três requisitos alternativos: a) Não estar edificada; b) estar subutilizada; c) não estar sendo utilizada.” (ROSENVALD; FARIAS, 2011, p. 253).

A partir disto, surgem três instrumentos normativos administrativos, quais sejam: o parcelamento do solo; a edificação compulsória e a utilização compulsória. Essas medidas administrativas consistem em obrigação propter rem $^{3}$ que recai sobre o titular do direito de propriedade.

O parcelamento do solo urbano constitui obrigação que, com atenção voltada à Lei $n^{\circ}$ 6.766/79, haverá o desmembramento ou parcelamento que permite a abertura de vias e logradouros.

A edificação compulsória impõe que haja construção no lote desmembrado, e ainda, que esta construção esteja em consonância com o plano diretor.

A utilização compulsória, é a forma pela qual o município constrange o proprietário a utilizar a propriedade conforme diretrizes impostas no plano diretor. No entanto, esta última sanção não tem previsão constitucional o que tem levado a questionamentos acerca de sua constitucionalidade. Sobre este instrumento normativo, posiciona-se aqui conforme orientação de Nelson Rosenvald e Cristiano Farias:

A posição que parece mais favorável, sem dúvida, é a de que não há
inconstitucionalidade, pois a medida de utilização compulsória é menos restritiva ao
direito de propriedade que o parcelamento e a edificação compulsórios. Ademais, o
$\S 2^{\circ}$, do art. 182 , da Constituição é uma cláusula geral, que permite a criação pelo

\footnotetext{
${ }^{3}$ A obrigação propter rem é àquela que recai sobre uma pessoa em razão da sua qualidade de proprietário ou de titular de um direito real sobre determinado bem.
} 
legislador subalterno de instrumentos capazes de concretizar a função social da cidade. (ROSENVALD; FARIAS, 2011, p. 254).

Feitas essas considerações, volta-se o foco da função social da propriedade urbana que permite, através de todas essas possibilidades administrativas, que as propriedades subutilizadas, não edificadas e não utilizadas passem a atender a demanda social e cultural.

Significa dizer, por exemplo, que havendo uma área que tenha imóveis fechados ou abandonados e por outro lado, havendo demanda para que essa área seja utilizada com o cunho habitacional ou cultural, caberá ao plano diretor declarar este espaço como subutilizado e destiná-lo ao fim que se necessita.

A frustação da expectativa que se propõe o plano diretor servirá de parâmetro para que o município qualifique a propriedade como subaproveitada, senão, assim, segundo Nelson Rosenvald e Cristiano Chaves de Farias (2011) essa aferição é quantitativa, posto que "verificase se está aquém dos níveis mínimos de aproveitamento definido no plano diretor, por não alcançar qualquer parâmetro de aproveitamento para a concessão de benefícios à coletividade local”. (ROSENVALD; FARIAS, 2011, p. 255)

No entanto, a desapropriação-sansão não é a última medida adotada pelo Estado, conforme orienta Pedro Lenza (2012), “já que primeiro, procede-se ao parcelamento ou edificação compulsórios e, em seguida, à imposição do IPTU progressivo no tempo, para, só então, passar-se a desapropriação-sanção”. (LENZA, 2012, p.691)

Desta forma, a propriedade que não cumpre a sua função social estará apta a servir a coletividade, quando assim qualificada pelo Município dentro dos parâmetros já estabelecidos e por força do poder de polícia conferida à administração pública.

Caracteriza-se por uma limitação e condicionamento da propriedade privada impondo-lhe uma obrigação de fazer ou deixar de fazer, com o fim de privilegiar o interesse público em detrimento do interesse particular, e consequentemente, assegurar a utilização da propriedade como relação jurídica que se estabelece entre o titular do direito de propriedade, o bem e a coletividade que pressupõe o desenvolvimento social da propriedade urbana.

\section{REGULARIZAÇÃO FUNDIÁRIA URBANA}

A definição de regularização fundiária pode ser encontrada no art. 46, da Lei $\mathrm{n}^{\circ}$ 11.977/2009, que dispõe que: 


\begin{abstract}
A regularização fundiária consiste no conjunto de medidas jurídicas, urbanísticas, ambientais e sociais que visam à regularização de assentamentos irregulares e à titulação de seus ocupantes, de modo a garantir o direito social à moradia, o pleno desenvolvimento das funções sociais da propriedade urbana e o direito ao meio ambiente ecologicamente equilibrado". (BRASIL; 2009).
\end{abstract}

Segundo Paiva (2012), a natureza jurídica da regularização fundiária em sua dimensão jurídica "constitui um processo de natureza administrativa, cujo rito procedimental é dotado de duas fases distintas, nas quais são praticados diversos atos administrativos". O autor se refere a primeira fase como sendo aquela em que há a legitimação da posse; a segunda diz respeito à aquisição da propriedade por meio do instituto jurídico da usucapião extraordinária. (PAIVA, 2012, p.08).

A lei supracitada trata ainda de diferenciar três modalidades de regularização fundiária, quais sejam: a) a regularização fundiária de assentamentos urbanos em termos genéricos; a regularização fundiária de interesse social; b) a regularização fundiária de interesse específico.

Em síntese, a regularização fundiária de assentamentos urbanos, está prevista nos Artigos 46 e 52, da Lei $n^{\circ}$ 11.977/09, que estabelece que na regularização fundiária em que houve assentamentos consolidados, antes do advento da lei supracitada, poderá o município autorizar a "redução das áreas destinadas ao uso público e da área mínima dos lotes definidos na legislação de parcelamento do solo urbano".

A regularização fundiária de interesse social é aquela que tem como objetivo o "de assentamentos irregulares ocupados, predominantemente por população em baixa renda" (artigo 47, VII, da Lei no 11.977/09).

Por fim, a regularização fundiária de interesse específico se contra prevista no artigo 47, VIII, também da Lei $\mathrm{n}^{\circ}$ 11.977/09, que dispões que ela se da "quando não caracterizado o interesse social, nos termos do inciso VII".

Neste sentido, malgrado as modalidades de regularização fundiária sejam de estrema importância ao desenvolvimento urbano, o próximo capítulo desta pesquisa tem como objeto de estudo a regularização fundiária urbana de interesse social que, notadamente, traduzem o interesse em consolidar a função social da propriedade urbana e o direito à moradia.

\title{
5. REGULARIZAÇÃO FUNDIÁRIA URBANA DE INTERESSE SOCIAL
}

A regularização fundiária de regularização urbana de interesse social possui uma íntima relação com os direitos e garantias fundamentais estabelecidos na Constituição da 
República e constitui meio pelo qual se concretiza o instituto da função social da propriedade urbana. A previsão normativa se encontra expressa no inciso VII, do artigo 47, da Lei $\mathrm{n}^{\circ}$ 11.977/09, que autoriza esta intervenção nos casos:

\begin{abstract}
a) em que a área esteja ocupada, de forma mansa e pacífica, há, pelo menos, 5 (cinco) anos; b) de imóveis situados em ZEIS; ou c) de áreas da União, dos Estados, do Distrito Federal e dos Municípios declaradas de interesse para implantação de projetos de regularização fundiária de interesse social. (BRASIL, 2009)
\end{abstract}

Conforme exposto, a regularização fundiária tem como finalidade regular as situações fundiárias existentes que estejam em desconformidade com os comandos normativos constantes no ordenamento jurídico brasileiro. Destarte, essas situações, por sua origem, estejam ilegais, possuem o amparo de prerrogativas constitucionais que justificam a sua regularização.

\footnotetext{
O direito de propriedade aparece como direito fundamental (art. $5^{\circ}$, XXII); porém a propriedade terá que atender a sua função social (art. $5^{\circ}$, XXIII, situação esta que se desdobra no âmbito da política urbana (art. 182 e 183), no âmbito da política agrícola e fundiária, bem como da reforma agrária (arts. 184 a 191)." (LENZA; 2012, p. 1252).
}

É evidente que a função social, a que deve servir a propriedade, constitui fundamento para a existência desta modalidade de regularização fundiária, posto que sua implementação, consequentemente, transfere o bem, que não foi utilizado para os fins que se destinam, à população de baixa renda.

Outro fundamento Constitucional que se utiliza para justificar a regularização fundiária se encontra no artigo $6^{\circ}$, caput, da Constituição da República, que inclui, como direito social, o direito à moradia. Malgrado este direito fora introduzido no ano de 2000, pela Emenda Constitucional (EC) $n^{\circ} 26$, essa prerrogativa já se encontrava prevista nos termos do artigo 23, IX, da CR/88, que concede à administração pública a competência de "promover programas de construção de moradias e melhorias das condições habitacionais e de saneamento básico." (LENZA; 2012, 693).

No entanto, a realidade brasileira não condiz com a formalidade que requer o ordenamento jurídico. A moradia, por razões históricas e estruturais, nem sempre se encontra nos moldes da legislação, e é justamente para harmonizar esse impasse que se utiliza da regularização fundiária de interesse social. 
Pode-se verificar, no entanto, que ainda existem limites que dificultam a transferência da propriedade através da intervenção por regularização fundiária de interesse social.

Exemplo disso é o caso hipotético em que há uma população de baixa renda que ocupa uma área particular, de maneira irregular, a menos de cinco anos, sem oposição do proprietário. Neste caso, não haverá a transferência da propriedade, haja vista que não houve o preenchimento de um dos pressupostos para que haja a prescrição aquisitiva, qual seja: o lapso temporal previsto.

Ou seja, embora possa haver a necessidade de aquisição dessa área, o pleito para a Usucapião Urbana, prevista no artigo 183 da Constituição da República, se torna ineficaz. No entanto, há evidência de que houve uma preocupação neste sentido quando se é possível a concessão de um título de posse com o objetivo que este venha a ser convertido em título de propriedade. Conforme orienta Paiva (2012):

\begin{abstract}
O processo de regularização fundiária, visando a regularização jurídica da propriedade imobiliária informal, é recentíssimo e sui generis na ordem jurídica do país, porque é a única hipótese, fora da via judicial, de formação de um título de propriedade para imóveis, fundado na posse prolongada, culminando com a aquisição da propriedade imobiliária por meio da usucapião. Para isso, opera-se a conversão do título de posse em título de propriedade. Assim, há, incialmente, a formação de um título de posse, chamado de título de legitimação de posse, emitido pelo poder público (constituído a partir da averbação inicial do auto de demarcação urbanísticas e demais providências previstas em lei), o qual, depois de registrado e de transcorrido o prazo do usucapião, será convertido em título de propriedade plena, por ato do oficial de registro de imóveis, a requerimento do interessado, que deverá produzir a prova exigida em lei para a concessão da conversão. (PAIVA, 2012. p.10).
\end{abstract}

De tal modo, o direito à propriedade, na maioria das vezes, é que sustenta o fundamento da regularização fundiária de interesse social de maneira que a própria regularização pode ser tornar mecanismo capaz de conferir função social à propriedade que não alcança este fim.

Neste sentido, a regularização fundiária pode se constituir através do pleno desenvolvimento urbano constante no próprio estatuto da cidade, conforme se verifica no art. $2^{\circ}$, Inc. XIV, que dispõe:

A política urbana tem por objetivo ordenar o pleno desenvolvimento das funções sociais da cidade e da propriedade urbana, mediante as seguintes diretrizes gerais: XIV - regularização fundiária e urbanização de áreas ocupadas por população de baixa renda mediante o estabelecimento de normas especiais de urbanização, uso e 
ocupação do solo e edificação, consideradas a situação socioeconômica da população e as normas ambientais. (BRASIL; 2001).

Desta forma, a norma supracitada busca atender ao comando Constitucional do artigo 186 que orienta que "a propriedade urbana cumpre sua função social quando atende às exigências fundamentais de ordenação da cidade expressas no plano diretor".

Pode-se perceber que o comando retro mencionado não delimita a maneira com que serão aplicadas as premissas, contudo, remete esse poder à norma infraconstitucional.

No entanto, há de se considerar, segundo orientam Nelson Rosenvald e Cristiano Chaves (2001), que há um aspecto material, no que tange à propriedade privada, que limita essa intervenção, e está prevista no artigo $182, \S^{\circ}$ da Constituição da República, que, conforme visto, considera que o solo urbano não cumpre a função social quando não está sendo utilizado, está subutilizado ou não edificado.

Neste contexto nasce um direito público subjetivo e um poder-dever do Poder Público. Sendo assim, seja por meio de sansões ou através de regularização fundiária de interesse social, cabe ao Estado dar o fim que atenderá à função social; havendo omissão por parte do Poder Público, poderá haver responsabilidades civis.

Contudo, há de se considerar que a intervenção do Poder Público sobre a propriedade a fim de regularização fundiária deve, assim como todo o ordenamento jurídico, estar em consonância com a dignidade da pessoa humana.

Neste diapasão, se torna inadmissível a permanência dessa população de baixa renda em imóveis que não estejam dentro dos padrões do mercado formal. Sendo assim, considera- se inviável a utilização de áreas próximas a rios e córregos, terrenos de alta declividade, áreas próximas a redes de alta tensão.

É evidente que ao desconsiderar essas peculiaridades, esses locais, ora destinados com a finalidade de regularização urbana, se tornarão assentamentos precários, resultado da administração por parte dos moradores e da autoconstrução do espaço.

Certo é que a ação do Estado ensejará o nascimento de novas irregularidades, novas favelas e loteamentos clandestinos, o que, consequentemente, tende a estimular a marginalização espacial e social.

Portanto, torna-se responsabilidade do Poder Público implantar o sistema viário, bem como a infraestrutura necessária à regularização. 


\section{CONCLUSÃO}

Desde os primórdios a propriedade possui uma ligação íntima com o seu titular. A concepção da propriedade no período Romano denota claramente que através da propriedade há a realização, seja pessoal ou em conjunto.

A vinculação da propriedade aos ascendentes, malgrado seja uma concepção inadmissível em um Estado Democrático de Direito, evidenciava que a convivência familiar se torna possível com a propriedade.

No entanto, embora essa concepção seja ultrapassada, o direito de propriedade continua sendo tutelado pelo ordenamento jurídico, por se este um elemento essencial para a convivência social, conjuntamente com o direito à moradia, e, primordialmente, vinculado à Dignidade da Pessoa Humana.

A evolução da propriedade absoluta para a propriedade-função significou um grande avanço social. Contudo, o atual cenário de áreas ocupadas de forma irregular, evidenciam a necessidade de criação de novos modelos de urbanização e uma maior proteção estatal, que, inclusive, objetive efetivar o direito à moradia, considerando que a Constituição deve priorizar o direito a vida, e mais que isso, a uma vida digna.

É imprescindível salientar que os direitos que acabam por não atingir à população de baixa renda desencadeiam vários outros problemas sociais, o que significa um retrocesso das primazias e pretensões da Constituição da República.

Neste sentido, ainda que a regularização fundiária seja um meio pelo qual se busca tutelar direitos fundamentais, pode-se afirmar que tais medidas se tornam visivelmente insuficientes para se alcançar tal finalidade de forma mais abrangente.

As diferenças regionais e sociais carecem de mais atenção do poder público de forma que não seja regra de habitação, mas uma exceção.

Por fim, conclui-se que, embora os progressos sociais e econômicos mereçam considerável respaldo, ainda há muito que se avançar para que a sociedade se amolde aos ditames da função social da propriedade urbana e da justiça social, posto que esta última não convive conjunta e harmoniosamente com as diferenças regionais e sociais que colocam os indivíduos menos favorecidos em uma posição de marginalização, ferindo, sobretudo, a sua dignidade. 


\section{REFERÊNCIAS}

BRASIL. Constituição da República Federativa do Brasil de 1988. Diário Oficial da União, Brasília, 5 out. $1988 . \quad$ Disponível em: <http://www.planalto.gov.br/ccivil_03/constituicao/ConstituicaoCompilado.htm>. Acesso em: 21 jul. 2015.

BRASIL. Lei $\mathbf{n}^{\mathbf{0}} \mathbf{1 0 . 2 5 7}$, de 10 de julho de 2001. Regulamenta os arts. 182 e 183 da Constituição Federal, estabelece diretrizes gerais da política urbana e dá outras providências. Diário Oficial da União, Brasília, 10 jul. 2001. Disponível em: <http://www.planalto.gov.br/ccivil_03/leis/LEIS_2001/L10257.htm>. Acesso em: 10 jul. 2015.

BRASIL. Lei $\mathbf{n}^{\mathbf{0}} 11.977$ de 07 de julho de 2009. Dispõe sobre o programa Minha Casa, Minha Vida - PMCMV e a regularização fundiária de assentamentos localizados em áreas urbanas. Diário Oficial da União, Brasília, 7 jul. 2009. Disponível em: < http://altinopolis.sp.gov.br/wp-content/uploads/2013/10/01Lei-Federal-11977-de-072009.pdf>. Acesso em: 10 jul. 2015.

CARVALHO, Kildare Gonçalves. Direito Constitucional. 16. ed. Belo Horizonte: Del Rey, 2010.

FARIAS, Cristiano Chaves de; ROSENVALD, Nelson. Direitos Reais. $7^{\mathrm{a}}$ ed. Rio de Janeiro: Lumen Juris, 2011.

FIÚZA, César. Direito Civil: Curso Completo. 15ª ed. Belo Horizonte: Del Rey, 2012.

LENZA, Pedro. Direito Constitucional Esquematizado. 16ª Ed. São Paulo: Saraiva, 2012.

LOUREIRO, Francisco Eduardo. PELUSO, César (coord.). Código Civil comentado. $2^{\mathrm{a}}$ ed. São Paulo: Manole, 2008.

MILARÉ, Edis. Direito do ambiente: Doutrina, jurisprudência, glossário. 3. ed. rev. atual. e ampl. São Paulo: Revista dos Tribunais, 2004.

PAIVA, João Pedro Lamana. DOS SANTOS; Francisco Rezende, COUTO; Maria do Carmo de Rezende Campos, SOUZA; Eduardo Pacheco Ribeiro de . (coord.) Coleção de Cadernos IRIB - Regularização fundiária de interesse social. $1^{a}$ Ed. São Paulo: IRIB, 2012.

RIBEIRO, Paulo Hermano Soares. Novo Direito Sucessório Brasileiro. 1.ed. São Paulo: J.H Mizuno, 2009. 